\title{
Tuning into Children's Voices: Exploring the Perceptions of Primary Aged Children about Their Education in One Primary School in England
}

\begin{abstract}
Jonathan Glazzard*
Corresponding author: Jonathan Glazzard, University of Huddersfield, School of Education and Professional Development, Queensgate, Huddersfield, UK, HD1 3DH. E-mail: j.glazzard@hud.ac.uk
\end{abstract}

Received: June 14, 2012 Accepted: August 6, 2012 Published: August 27, 2012

doi:10.5296/ije.v4i3.1933 URL: http://dx.doi.org/10.5296/ije.v4i3.1933

\begin{abstract}
This small scale study examined children's views about their education in one primary school in England. The research took place in a large primary school, situated in an area of relative social deprivation in a northern town. A focus group was used to elicit the views of children in Key Stage 2 (aged 7-11) about their teachers, the curriculum, assessment and school inspection. Although the findings cannot be generalised, pupils had mixed views about reading, writing and mathematics. However, they were unanimous in their dislike of science. The data also indicate that pupils felt that the processes of testing and school inspection both served important purposes and that external validation of the school's performance was necessary. This study provides a springboard for further research into pupils' perspectives of their primary education.
\end{abstract}

Keywords: pupil voice, primary school, curriculum, inspection, teaching, learning 


\section{Introduction}

A growing interest in pupil voice over the last two decades has resulted in seminal work being published. Key studies include the work of Pollard and Triggs (2000) and Ruddock and Flutter (2000, 2004). School inspections in England now focus heavily on pupils' perspectives of their schools, their teachers and their learning environment and current education policy focuses ways of increasing pupil participation in decision making. The growth of child-centred approaches in education over the last thirty years can, perhaps, be attributed to the Plowden Report in 1967 (CACE, 1967) which placed the child at the heart of the educational process.

This study, whilst small-scale, seeks to contribute to the existing body of knowledge within this field of enquiry. The school was built in the 1950s and is situated in a working class area in a suburb of an industrial town. The school is a community primary school that has academy status. Within the local authority the school is highly regarded and it was judged to be an outstanding school in its previous inspection by the Office for Standards in Education (OFSTED). The school ethos reflects the importance of partnership working and the central role of parents in raising attainment. Parents are welcomed into the school and the leadership team has focused extensively on developing links with the local community and local organisations during the past few years. Within the school there is a constant focus on school improvement. The school has established strong links with the local University and academics from the University form part of the school leadership team.

There is now an increasing need to listen to pupil voice and this is reflected in current education policy in England. Literature which explores pupils' perspectives of their education includes research by Robinson and Fielding (2010), Fielding (2001), MacBeath et al (2003), Rudduck et al (2006) and Rudduck and Flutter (2004). Research indicates that pupils see primary school as a base for future employment (Silcock and Wyness, 2000). In addition, pupils also see school as a social setting where they make friends (Cullingford, 1986).

Research indicates that boys perceive that teachers do not treat them in the same manner as girls. Boys feel that girls receive preferential treatment from teachers and consequently boys feel a sense of injustice (Myhill and Jones, 2006). Research generally indicates that pupils are very enthusiastic about their early education but their enthusiasm wanes as they get older (Pell and Jarvis, 2001). There are now moves to increase a sense of negotiated power between pupils, teachers and head teachers (Robinson and Fielding, 2010) and greater pupil participation in decision making within schools. This would then bring schools in-line with current policy which emphasises the need for educators to listen to and act upon pupils' perspectives. Teacher apprehension regarding pupil power and the 'apparent' erosion of their professionalism (Robinson and Fielding, 2010) can create tensions for those teachers who may be reluctant to transfer ownership of education to their pupils. 


\section{Literature Review}

\subsection{Pupils' views on the curriculum}

As pupils get older they find reading increasingly complex which in turn reduces their motivation (Pollard and Triggs, 2000). Additionally, research has found that young children generally dislike writing although older children appear to enjoy the technicality of handwriting (Pollard, 1996). More recent research by Lord and Jones (2006) has found that although younger children enjoyed writing, enthusiasm for writing appeared to decline amongst older children (Lord and Jones, 2006). Research by Bearne (2002) found that children aged 7-8 years enjoyed writing in the home but found the demands of writing in school challenging due to the need for them to demonstrate achievement. Research suggests that pupils dislike writing tasks, listening to the teacher reading stories, sitting still for long periods of time, recording their ideas and the lack of opportunities for personal autonomy within their writing (Cullingford, 1991; Pollard and Triggs, 2000 and Kinder et al, 1996).

Pollard and Triggs (2000) found that pupils in England generally enjoyed the core subjects (English, mathematics and science) during the infant phase of their education but were demotivated in these subjects during the junior phase due to the excessive assessment demands placed upon them. The pupils in the junior phase began to favour practical subjects which allowed pupils to take ownership of their learning and which also provided a welcome respite from the taxing core curriculum (Cullingford; 1991).

In terms of mathematics research has indicated that pupils are very aware of the importance of mathematics and its part in their long term future (Silcock and Wyness, 2000). Pollard and Triggs (2000) found that the two extremes of mathematical ability were confident in mathematics. The high ability children felt confident because they had mastered the processes of mathematics, whilst the less able children could experience success due to the scaffolding provided through the provision of differentiated tasks. Pupils in the middle ability range were more likely to find mathematics problematic and become concerned about it. Pollard and Triggs' (2000) research demonstrated evidence of differential attitudes towards mathematics amongst boys and girls with boys demonstrating more positive attitudes towards mathematics than girls in the junior years.

Research has indicated that pupils are enthusiastic about science (Reid and Skaryabina, 2002; Harland et al 1999) although more recent research has indicated a decline in popularity for science towards the latter end of the junior phase of education (Pell and Jarvis, 2001). Research by Pollard in 1996 indicates that pupils disliked writing during science lessons and Lord and Jones (1996) found that pupils preferred practical activities during science; this is further supported by Pell and Jarvis (2001). Pollard and Triggs (2000) also found that science was marginalised in the curriculum until Years 5 and 6 (aged 9-11), where there was a sudden increase in pupils being asked to write about science. Pupils also expressed concern about the over-load of scientific content (Pollard and Triggs, 2000). However, research with younger pupils suggests that children in the infant years are enthused by the newness of scientific activities and are generally motivated in science (Pollard and Filer, 1996; Pell and Jarvis, 2001; Lord and Jones, 2006). 


\subsection{Pupils' perspectives on teaching and learning}

Research by MacGilchrist and Buttress (2005) found that pupils find it useful when teachers share clear learning intentions with the class. Additionally, pupils value peer support with their learning (Bearne, 2002; Cullingford 1991; Demetriou, Goalen and Rudduck, 2000; Flutter and Rudduck 2004; McCallum and Demie, 2001; Pollard and Triggs, 2000). Research has indicated that pupils sometimes value the use of non-friendship groups to enable them to stay focused and on task (Flutter and Rudduck, 2004; Pointon and Kershner, 2000; Silcock and Wyness, 2000). Pupils are motivated by teachers who make lessons interesting and active and also teachers who challenge them but give them the freedom to fail (Blatchford, 1992; Pollard and Triggs, 2000). Additionally pupils like to be praised and rewarded but are demotivated with routine, repetitive tasks and lack of challenge (Cullingford, 1991; Pollard and Triggs, 2000) Pupils dislike repeating previous work or recapping but enjoy activities that are purposeful and do not waste their time. They enjoy physical activity that increases their engagement (Futter and Ruddock, 2004). Pollard and Triggs (2000) suggest that pupils are very aware of the difference in expectations from different teachers and value the opportunity to have greater autonomy over what is being taught and learnt.

\subsection{Pupils' perspectives on testing}

Published research has found that pupils 'tolerate' testing; some pupils enjoyed the challenge of the tests whilst others became worried, anxious or fearful of the tests (Bearne, 2002; Doddington et al, 2001; Silcock and Wyness, 2000). Research by Doddington et al showed that pupils become worried when they did not know the purpose of assessment as they feared that the tests would 'discover' their short comings rather than reward their achievements. Doddington and Flutter (2002) found that the way in which teachers explained the purpose of testing was critical to the pupils' confidence and that in some schools the tests made pupils conscious of what they could not do rather than what they could do. Reay and Wiliam (1999) have identified pupil anxiety regarding the statutory assessment tests. Pupils saw the results of these tests as having long term consequences for them. They perceived that good results brought about prosperity and wealth while poor results brought about failure and a poor standard of living. Robinson and Fielding (2010) have identified that pupils are very aware that it is more important to have achieved successfully than the effort they put into the tests, although they perceive effort as worthy. Pollard and Triggs (2000) found that schools that created a non-threatening environment during the testing period resulted in pupils being more confident. However if pupils are placed under pressure they become de-motivated and overwhelmed by the challenges of the statutory tests. Pupils appear to be very aware of the accountability functions of the tests in that test results would be used to assess teacher performance (Reay and Wiliam, 1999).

\subsection{School inspections}

There is very limited literature regarding pupil views of inspection (Cunningham and Raymont, 2010). School inspections in England have been carried out by the Office for Standards In Education (Ofsted) since 1992. Prior to this school inspections were carried out by Her Majesties Inspectorate of Schools (HMI) which was founded in 1839. From 1996 
individual teachers were graded on their teaching performance by Ofsted inspectors. Woods and Jeffery (2002) identified how primary teachers have had to re-construct their professional identities in response to increasing government control of education and Case, Case and Catling (2000) found that teachers staged-managed performances for inspectors. Research by Brunsden, Davies and Shevlin (2006) reported unhealthy anxiety in teachers before, during and after inspections. The process of inspection rather than the outcome generated anxiety for teachers. Within England school inspections have become a means of controlling teachers as well as schools (Cunningham and Raymont, 2010).

\section{Method}

The data was collected using a mixed focus group of children aged between 7-11 years. 12 pupils contributed to the focus group and there was an equal split of boys and girls. The focus group was selected by members of the schools Senior Leadership Team. The data was recorded using a digital recorder and later transcribed. Key themes were identified from the transcripts

\subsection{Guiding research questions}

This study sought to address the following questions:

- What perspectives did pupils hold on the primary curriculum?

- How did the pupils conceptualise good and bad teachers and good and bad lessons?

- Did the pupils feel that they had a say in their education?

- What were the pupils' perspectives on testing, assessment and school inspections?

\section{Results and Discussion}

The interview schedule was designed to collect the pupils' perspectives on their teachers, the taught curriculum, lessons, the extent to which they felt they were consulted and their views on assessment and inspection. The findings from the research are summarised below.

\subsection{Perceptions of teachers}

The children had a clear sense of what makes a good teacher. They perceived that good teachers are fair, kind, fun and try to make their lessons interesting. However, there was also a feeling that good teachers are strict when children are not working to their full potential or when children are disruptive or non-compliant:

Good teachers are kind and fair. They are patient with you and don't rush you when you are working. They give you time (Sam)

Good teachers make lessons fun. They don't shout at you. They are patient. (Ryan)

They are funny and make me laugh and smile but they are also a bit strict (Frances).

They help you and they are kind to you when you are struggling and good teachers are strict when you are not working as hard as you should (Jasmin). 
They let you work with your friends. They let you work in groups (Toheed).

Good teachers are fun and kind. They wait for us and they go back over things that we do not understand. They spend time with you and they show an interest in you (Emily).

They make lessons fun. They play games with you (Lee).

In describing their perceptions of 'bad' teachers a key recurrent theme across the data related to issues of respect for children and fairness. The children in the focus group perceived bad teachers to be those who shout at children and those who do not listen to children. In this category they referred to teachers who wrongly blamed children for misdemeanours and teachers who did not speak to children in a respectful manner. They also conceptualised 'bad' teachers as those teachers who find it difficult to explain concepts or those who lack subject knowledge:

We had a really bad teacher in class 4. She wouldn't listen to us. She upset us and she made us cry. She shouted at us and told us to shut up. She did not speak to us very nicely. (Sam)

I have seen a bad teacher. She was really mean and strict. (Sarah)

She was really strict and not fun! She didn't listen to me. She blamed everything on me and told me I was lying. (David)

They shout at you, even when you are not doing anything. They humiliate you! (Jack)

She blamed things on me that were not my fault. She would not listen to what I was saying. (Lauren)

She did not really explain the activities. It makes you feel upset as you want to know how to do things but you don't because it has not been explained properly. (Emily)

We had a teacher in class 4 who added numbers up incorrectly. We tried to tell her but she shouted at us. (Frances)

Bad teachers teach us wrong, like in maths when they do not know how to do something themselves. (Toheed)

We had a supply teacher who did not know how to use the interactive whiteboard. We tried to tell her and she wouldn't listen to us and told us to shut up! (Emily)

The children in the focus group had no respect for those teachers who failed to listen to their perspectives. The children exhibited a strong sense that they had a right to be listened to and that their views were equally important to those of their teachers. There was a shared sense amongst the pupils that teachers should treat children fairly and respectfully.

\subsection{Views about literacy}

The data from the focus group indicate that pupils had divided opinions about literacy. The boys appeared to prefer reading and writing non-fiction texts and several boys spoke at 


\section{Macrothink}

International Journal of Education

ISSN 1948-5476

2012, Vol. 4, No. 3

length about a current project on the Amazon Rainforest that they had been undertaking in class. The boys appeared to be highly motivated by this theme. They appeared to have enjoyed reading and writing factual information about the rainforest and spoke at length about some of the facts that they had discovered. Contexts for reading and writing were also an emerging theme, although the small sample size makes it impossible to generalise. One boy spoke about being motivated by books which involved murder and other types of crime and football. The pupils also appeared to dislike poetry because of its complexity and one boy enjoyed using the computer for writing:

I like reading about crime, murder or football. (Lee)

I like reading stories, not facts. (Jasmin)

I love reading non-fiction books. We have been finding out about the Amazon rainforest and I love reading the books to find things out, although some of the words are hard. (David)

Sometimes there are too many difficult words to read but it's OK. I prefer short books so that I can get through stories quickly. (Ryan)

I like moving through the bands. Each band has a different colour-red, orange, free readers. (Emily)

I don't like shared reading- it is boring reading through a whole story or part of a story, especially if I am not interested in it! I hate reading traditional tales but I love reading about cars. (Jack)

I'm good at writing and it makes me think, although I find writing poems tricky. (Frances)

I like writing facts about the Amazon rainforest as I find it really interesting. (Sam)

I don't like writing. It makes your hand hurt. I hate sharpening my pencil. It hurts my hand. (Toheed)

I can't write the letters properly. I prefer to write on the computer. I like using different fonts and dropping in pictures instead of using a pencil. (David)

I don't like story writing because I don't have an imagination. I find it hard to think about what to write. (Ryan)

I prefer writing facts. We are learning about World War 2 and I like writing about that. (Sam)

Ryan's comment about lacking imagination is important. Within this school many of the children's experiences outside school are restricted and the majority of children do not visit places of interest or read for pleasure. Such experiences inevitably shape the imagination and children who have read for pleasure or visited interesting places are able to draw on these experiences to create their own engaging narratives. Teachers cannot assume that children will have experienced the pleasure of visiting forests, caves and ancient ruins. Additionally, 
teachers cannot assume that children will have been immersed in imaginative worlds through exposure to children's literature.

Many of the children in the research school have not left their home town for holidays or visited places of interest due to various reasons. Within this context it is vital that teachers do all that they can to facilitate the development of children's imaginations. Children need access to a creative and imaginative teacher who models the use of descriptive vocabulary when describing objects or places. Additionally, children need opportunities to talk in a creative way before being asked to write creatively. Short openers to lessons which focus on the development of creative thinking will provide children with the confidence to explore creative ideas. Asking children to work in pairs to produce an oral description of an imagined or real place or object is the beginning stage of getting children to write in a creative way. Children need to think creatively before they can write creatively. Children will produce richer ideas if the teacher models creative thinking and problem solving. Asking children to innovate a known story by changing a character, event, the setting or the ending is one way of scaffolding children's imaginations. This provides children with a framework for being imaginative without the necessity to create a story from scratch. Providing children with opportunities to orally rehearse stories in pairs provides an important opportunity for children to provide oral feedback to their peers prior to the writing process. Providing access to digital media such as film clips may also allow children to access imaginary worlds. Engaging children in reading for pleasure is clearly important and this is something which the teacher can model. However, the importance of thinking and talking creatively and oral rehearsal prior to the writing process should not be underestimated.

The importance of providing children with contexts and purposes for reading and writing emerges in both David and Lee's comments. Lee's motivation for crime, murder and football provide a useful context for his work. David's motivation for factual texts to further his own knowledge also provides a valuable opportunity for engaging him in reading. These voices suggest that there is value in teachers capitalising upon children's interests and using these as contexts for engaging children in reading and writing. However, the current literacy curriculum in England requires children to read and write in a range of genres as was evident in Jack's case where he spoke of a dislike for reading traditional tales. Teachers therefore need to find ways of engaging children in a range of genres by drawing on children's interests. Jack's interest in cars could have been used to produce an imaginative and original version of a traditional tale and Lee's interest in crime, murder and football could be used as a context for engaging Lee in a range of genres.

\subsection{Views about mathematics}

In the focus group there was a shared view that pupils enjoyed being challenged in mathematics. They disliked repeating work that they had covered previously and they enjoyed tasks which related to using and applying mathematics. It was impossible to draw any gender differences out of the data: 
I like doing my eleven times table. Miss gives me and Adam loads of sums. They are well hard but I like getting hard work. I love solving problems and finding my own ways of doing it. (Jasmin)

I don't like easy sums. I like it when they are a bit harder. (Claire)

I love all types of maths but I hate division. (Lauren)

It's boring - I find it boring when it is too easy, when it doesn't make me think. (Sarah)

We love real life problem solving. We had a budget and items to buy and we had to work out how much it would cost to pay people and how much it would cost to buy the materials. It was quite difficult. We have a special teacher who comes in to do problem solving. The whole class likes it. (Ryan)

Ryan's comment illustrates the importance of providing children with genuine purposes for doing mathematics. Children's motivation is likely to be maximised if there is a purpose for completing mathematical processes. An enterprise project, whereby children produce and market specific products, can serve as a vehicle for furthering children's mathematical knowledge and understanding. Opportunities for children to apply mathematics throughout the wider curriculum are fundamental for maximising children's engagement with mathematics. Jasmin's comment about using her own mathematical strategies raises important considerations: teachers can suggest and model strategies for solving mathematical problems but children do invariably develop their own strategies and their own ways of recording solutions to problems. Teachers should encourage children to develop their own pencil and paper strategies rather than insisting that children follow one method. Additionally, the importance of providing children with challenging work in mathematics was a theme that emerged through the data. This raises considerations in terms of teachers ensuring that they have adequate levels of subject knowledge so that they can challenge pupils and teachers taking responsibility for ensuring that they understand progression sequences within various strands of mathematics.

\subsection{Views about science}

Data from the focus group indicate a shared dislike of science amongst both boys and girls and therefore this is a fundamental area for further research. The children disliked writing up experiments and sometimes did not see the purpose of some of the investigations that they were being asked to carry out. The children found the scientific vocabulary complex:

We watch the teacher do an experiment then we have it do it. It is boring. (Lee)

I hate it. We have to draw the picture that our teacher draws. (Sarah)

I don't like it. It is really hard. I hated holding cotton wool with water-it feels disgusting. (David)

I enjoy doing the experiments but I don't like writing them up. (Jack) 
I absolutely hate science. It is really hard and boring. I just don't understand the words. (Claire)

I like doing the activities but I don't like writing it all down. (Lauren)

In science you get to use a magnifying glass and you get to do experiments. It made me laugh when I saw Adam's nose through the magnifying glass. (Jasmin)

We don't understand the words that the teacher uses. (Toheed)

We need more time to learn the words. We have had to start using the science words and I get mixed up with what they mean. (Ryan)

The comments by Toheed, Ryan and Claire highlight the importance of teachers ensuring that explanations of scientific vocabulary are clear and precise. Additionally, vocabulary should be age-appropriate and young children do not need to be introduced to over-complex vocabulary unless they have the cognitive ability to be able to process it. The importance of teachers demonstrating and explaining the practical application of scientific concepts to everyday life is something which should not be under-estimated. Lee's point about replicating the teacher's experiments raises interesting considerations about the extent to which teachers should define the structure of the activity and whether teachers should provide children with more autonomy over their scientific learning. Finding opportunities for children to develop their own experimental solutions to scientific problems is one way of increasing pupil autonomy. However, it is important that young children experience a sense of success in their learning and providing children with too much autonomy may lead to a sense of frustration and failure. Getting the balance right between teacher control and pupil autonomy is dependent upon children's cognitive abilities. However, allowing children to take greater control of their learning should be the ultimate aim of education, particularly as children progress through the primary years.

Lauren's comment raises interesting considerations about whether children need to record their scientific findings. Teachers should consider how children can document their learning and how they can capture the evidence of children's achievements in a range of ways rather than always asking children to record their learning through the written mode. Such developments would maximise pupil engagement in lessons and remove barriers to learning, participation and achievement for pupils with literacy difficulties, thus creating a more inclusive pedagogy.

\subsection{Views about lessons}

Some children in the focus group talked about the importance of clear teacher explanations. One child talked about how good lessons were those where he was able to research into things that he was interested in. The children were unanimous in their view that good lessons are those where they are allowed to talk about their work with other pupils and work together in a collaborative way. The children spoke at length about how they were motivated by lessons which were interesting and purposeful. They had a shared sense that some form of pupil activity in lessons is important for maintaining their levels of motivation. 


\section{$\triangle$ Macrothink}

International Journal of Education

ISSN 1948-5476

2012, Vol. 4, No. 3

They also had a shared view that in good lessons the climate in the classroom was productive for learning and disruptions were dealt with swiftly by the teacher:

Lessons are good if there are games to play and if people are quiet. (Claire)

If a lesson is really interesting we just want to get on with it and we don't like it when the teacher talks for too long. (Lauren)

I like lessons when I get things right and the teacher puts ticks on my work. (Jack)

I was interested in learning more about the Amazon rainforest and the teacher let me do more work on it. That was a good lesson! (David)

A lesson is good if there is a good teacher teaching it. My teacher is really good. She doesn't mumble. She says things very clearly and then gives us time to get on with our work. (Emily)

In lessons I like it when the teacher tells me what I am going to learn. If we don't get told what we are learning then we don't know. I don't like to sit and listen for a long time. I like to spend time on my work. (Toheed)

There was a strong sense that time spent on getting on with work was important to the children in the focus group and that teachers should not spend too much time on explaining the lesson content. Striking a balance between teacher talk and pupil activity is important to give children opportunities to demonstrate their knowledge and skills. However, the children in the focus group indicated that the balance between teacher talk and time on task should not be equal but weighted favourably towards pupil activity. The children demonstrated a clear understanding that in good lessons opportunities are provided for them to work harder than the teacher. Additionally, they demonstrated a shared sense that in good lessons teachers do not dominate lessons but maximise the use of time so that children can be productive.

Minimising teacher talk and maximising pupil activity provides optimal conditions for learning. However, it is also important that teachers explain concepts clearly and model the skills that the children will subsequently apply. Reducing teacher talk could have detrimental consequences if children do not fully grasp the concepts and skills which they are subsequently expected to demonstrate during a lesson. Conversely, over use of teacher modelling and explanations could limit opportunities for children to apply their learning. Teachers should consider how to structure lessons to reduce the time children spend sitting and listening to explanations at the beginning of lessons, thus maximising time for pupils to apply their learning. School inspections in England now focus sharply on the quality of learning within lessons and maximising the time that pupils spend on task will provide optimal conditions for pupils to demonstrate their learning. Too much teacher talk, teacher modelling and too much scaffolding of children's learning limits their learning by reducing the time that pupils can work independently. In England, recent OFSTED inspections in schools have focused on evaluating the quality of teaching in terms of the impact that it has on pupils' progress and achievement. Thus, teaching is only deemed to be effective if it has a demonstrable, measurable impact on pupils' learning. 


\subsection{Pupil Voice}

The pupils in the focus group agreed that they were consulted in decision making processes and they felt able to effect change in the school. They had an emerging sense of their role as key partners within the school:

They take notice, If you want some more games for indoor play you can write it on a piece of paper and put it in a box and then school council talk about it. (Lee)

School Council has a meeting a meeting every week and talk about how they can improve the playground. It is run by the older children. (David)

We got a new climbing frame and shelter for the bikes and we are getting a tire swing park. (Jack)

You can put your suggestions in the suggestion box. They have changed the system for school dinners so we now get to choose the fillings for our sandwiches once a week. (Lauren)

In school council meetings school councillors decide if we have it. We wanted snakes and Ladders and now we have it. (Emily)

The school council sort it out and decide what we need. (Claire)

There was a clear sense that the mechanism for expressing their views was through the School Council. However it was evident that whilst pupils felt that they were consulted on matters relating to the classroom environment, playground and school lunches, they did not articulate ways in which pupil consultation had extended into matters relating to the school ethos, curriculum, teaching and assessment. It is possible that consultation with pupils in relation to these aspects of their education is embedded within an annual school improvement cycle. However there was no evidence that pupils were consulted on wider strategic issues relating to school improvement. The United Nations Convention on the Rights of the Child (1989) ensured pupils the right to participate in all matters which concern them (Noyes, 2005). The notion of listening to and acting upon pupils' voices demands a cultural shift in schools from a position whereby pupils are viewed as recipients of education to a position whereby pupils are viewed as partners in the processes of teaching and learning. Flutter and Ruddock (2004) have emphasised that pupil consultation can improve teaching and learning and MacBeath et al (2003) have argued that a commitment to the notion of pupil voice can reduce learner disengagement and enhance self-esteem. Additionally, Fielding and Bragg (2003) have emphasised how pupil engagement in every aspect of their education can result in students becoming agents of change, resulting in a fundamental change to the ethos of a school. Such a concept goes beyond notions that pupil voice can merely improve teaching and learning and reduce disengagement. As Noyes (2005) rightly points out 'voices are nothing without hearers' ( $\mathrm{p} .536)$. Opportunities to provide pupils with mechanisms to express their views results in tokenism if those views are not taken seriously and acted upon. Through 
a commitment to the notion of student as agents of change, children learn about democracy and their role as active citizens and this type of learning is equally important, if not more important than academic learning.

Schools need to carefully consider whose voices are listened to and privileged (Noyes, 2005). Bernstein (1977) emphasised how schooling reinforces inequalities by advantaging pupils who possess cultural and linguistic capital. It is critical that schools consider how to provide opportunities for those children who are less articulate to express their views. Schools need to consider how to provide opportunities for the youngest children and those children with special educational needs and disabilities to express their perspectives and take an active role in shaping their educational experiences. There was no evidence that this was the case within the research school. David's comment demonstrates that the youngest children were not part of the school council. It was notable that the school's leadership team did not allow the youngest children to participate within the focus group for this research and it was evident that the selected pupils were confident, able and articulate. Lauren's comment about the suggestion box privileges those pupils who are able to express themselves in the written form. The use of the school council as a mechanism for expressing pupil voice favours pupils who can articulate themselves using the power of speech. Within this context the school's commitment to pupil voice is questionable and it is possible that the policies related to pupil voice merely reinforce existing inequalities amongst children rather than empower all children.

If mediated properly a commitment to pupil voice opens up the potential for both students and teachers to critique the curriculum and educational processes. Noyes, 2005) points out that currently there is a lack of critical questioning about education in the United Kingdom. The curriculum is prescribed and the perfomative culture which pervades education gives schools very little room for manoeuvre. However, in schools where teachers and leaders are willing to critically question such prescription in policy and pedagogy, educators may also be more receptive to pupils' perspectives (Noyes, 2005).

Frequent consultation with pupils is critical in order to prevent schools from responding to the pupil voice agenda in ways that are tokenistic. There needs to be an ethos of mutual respect between teachers and students and educators need to view all children as social agents who are capable of making decisions about matters which concern them. Such a perspective on children demonstrates a departure from traditional perspectives of students as passive recipients of education.

\subsection{Views about assessment}

Data from the focus groups indicate that pupils saw the test results as serving an important function, i.e. to help them get a better job later in life. There was an emerging sense that pupils understood the purposes of self and peer assessment.

Tests help us to improve. They are important. (Jasmin)

We need to do tests to help us to get a better job. They are important. (Claire) 
I like the maths tests but none of us like the science tests. Not a lot of people in the class like science and it might ask us to explain a word and we don't understand. (David)

My mum said that the tests in Year 2 are not important but the tests in Year 6 are very important. (Sarah)

My mum says the tests don't matter. (Lee)

At the end of lessons we have smiley faces or sad faces. You choose a smiley face if you have understood the lesson and a sad face if you found the lesson difficult. If you don't tell the truth you'll never learn. (Emily)

Sometimes we mark each others' work using two stars and a wish! We use stars to say what they have done well and wishes for things they need to improve. (Frances)

Sometimes we read our work out to the whole class and others comment on the work. Sometimes we mark our own work. (Ryan)

\subsection{Views about inspection}

The children in the focus group unanimously felt that the inspection process was important for schools because of the role of external validation and the need for schools to be accountable. Sam's comment below emphasises the right of the public to know how well a school is doing. There was a sense that all members of the school community should work together to show the school in a good light during an inspection. There was also a shared view that inspection feedback should be used to help schools further improve and that negative feedback from inspectors should be used in a positive way to facilitate school improvement. This demonstrates a very mature view. There was no sense that the pupils viewed the inspection process in a negative light. In fact, there was a sense that inspection was necessary and helpful, if slightly nerve wracking:

If we didn't have inspections then every school would say that they are good but we wouldn't really know whether a school is good or bad. (Sam)

School inspections are quite important. It is good for an inspector to judge our school and if they tell us that there is something we need to improve then we know we have to work harder. (Ryan)

Inspectors judge the school and say whether it is good or bad. (Frances)

If the inspectors give us a bad report we just have to take it and try to get better. I would not be upset if we got a low grade as I love the school. (Jasmin)

We work as a team and when the inspectors come in we don't want anyone to let us down. (David)

They might give us a great grade so inspections are good. (Jack) 
It would be embarrassing if we didn't do well but I am not bothered. I love this school and my teachers so I would stay here. (Lauren)

We just act normal when they come into our classrooms but they make me nervous when they stand over me and look at my work. I don't want the school to get a low grade if my work is not good enough. (Claire)

The pupils in the focus group demonstrated a strong sense that they were partners within in the inspection process. It was clear that they had accepted that they had a responsibility to show themselves and their school in a good light to the inspectors. Ryan's use of the term 'we' suggests that he had a strong sense that he was part of the school community and that he also played a role in school improvement. David's comment about working as part of a team demonstrates that he had a strong sense that the children, teachers and leaders were working together during the process of the inspection. The children demonstrated a strong sense of agency. They understood that the inspection affected the whole school community and that they played a fundamental role in helping the school to do well in inspections. They clearly understood their role during an inspection and also their role in helping their school to improve further.

The children's perspectives, particularly in relation to school inspections, reflected a positive ethos which emphasised children's rights as full members of the school community, team work and the role of all members of the school community in engendering school improvement. Such an ethos is more likely to be internalised if children are involved in formulating the ethos. This was not explored as part of the focus group. Additionally, it was clear from the comments that the children made in the focus group that the leadership team regularly reiterated the school ethos to the children. The Head Teacher had created an honest, democratic climate in which the children accepted their responsibilities as partners in learning and school improvement processes. The children in the focus group had clearly accepted this level of responsibility and this gave them a strong sense of personal agency and confidence.

\section{Conclusion}

The pupils' perspectives highlighted in this study suggest that teachers may find it helpful to carefully consider how to draw upon children's own interests to provide them with stimulating contexts for reading and writing. Additionally, teachers might wish to consider how they can provide children with opportunities to use an apply mathematics throughout the broader curriculum. The pupils demonstrated a unanimous dislike of science. In view of this, teachers could consider how they might provide children with opportunities to develop their own scientific investigations in response to scientific problems rather than expecting children to repeat an investigation which has been demonstrated. Providing children with creative opportunities to respond to scientific problems might increase pupil engagement in primary science.

The pupils shared a sense of what makes a good teacher and a good lesson. They felt that good teachers needed to be respectful of pupils, fun in their character and have good 
subject knowledge. Good lessons were those where the pupils could be active and work in groups. Bad teachers had poor subject knowledge and were disrespectful of pupils' views.

Although it is not possible to generalise from this data, the pupils' perspectives presented in this paper indicate that the processes of inspection and assessment are both important and necessary for both for facilitating school improvement and for safeguarding their own careers. There was no evidence that assessment and inspection led to detrimental impacts on pupils. In contrast, the pupils seemed very aware that these processes enable schools to be accountable to key stakeholders.

The pupils felt that they were consulted about matters which immediately affected them such as the design of the school playground or school lunches, although there was no evidence that the pupils were consulted about wider strategic issues, such as aspects of school improvement or the school ethos. Schools should consider how they can engage children in democratic processes which extend beyond superficial matters, thus viewing students as change agents. Additionally, schools should also consider developing inclusive ways of consulting with pupils so that traditional inequalities are not reinforced.

\section{References}

Alexander, R. (2010). (Ed), The Cambridge Primary Review Research Surveys. London: Routledge.

Bearne, E. (2002). A good listening to: Year 3 pupils talking about learning. Support for Learning, 17, (3), 122-27. http://dx.doi.org/10.1111/1467-9604.00250

Bernstein, B. (1977). Class, codes and control, Vol. 3: Towards a theory of educational transmissions (2nd ed.). London: Routledge and Kegan Paul.

Blatchford, P. (1992). Children's attitudes to work at 11 years. Educational Studies, 18(1), 107-118. http://dx.doi.org/10.1080/0305569920180110

Brunsden, V., Davies, M., and Shevlin, M. (2006). Anxiety and stress in educational professionals in relation to Ofsted. Education Today, 56(1), 24-31.

Case, P., Case, S., and Catling, S. (2000). Please show you're working: a critical assessment of the impact of Osted inspection on primary teachers. British Journal of Sociology of Education, 21(4), 605-21. http://dx.doi.org/10.1080/713655370

Central Advisory Council for Education (England). (1967). Children and their Primary Schools (the Plowden Report). London: HMSO.

Cullingford, C. (1986). 'I suppose learning your tables could help you get a job' -children's views on the purpose of schools. Education 3-13, 14, (2), 41-46.

Cullingford, C. (1991). The inner world of the School: children's ideas about school. London: Cassell Educational. 


\section{Macrothink}

International Journal of Education ISSN 1948-5476 2012, Vol. 4, No. 3

Cunningham, P., and Raymont, P. (2010). Quality Assurance in English Primary Education. In Alexander, R. (2010) (Ed), The Cambridge Primary Review Research Surveys, London: Routledge, pp.767-91.

Demetriou, H., Goalen, P., and Rudduck, J. (2000). Academic performance, transfer, transition, and friendship: listening to the student voice. International Journal of Educational Research, 33(4), 425-41. http://dx.doi.org/10.1016/S0883-0355(00)00026-4

Doddington, C., and Flutter, J. (2002). Sustaining Pupils' Progress at Year 3. Cambridge: Faculty of Education, University of Cambridge.

Doddington, C., Bearne, E., Demetriou, H., and Flutter, J. (2001). Testing, testing, testing ... can you hear me? Can Year 3 pupils tell us anything we don't already know about assessment? Education 3-13, 29, (3), 43-46.

Fielding, M., and Bragg, S. (2003). Students as researchers: making a difference. Cambridge: Pearson.

Flutter, J., and Rudduck, J. (2004). Consulting Pupils: what's in it for schools? London: RoutledgeFalmer.

Harland, J., Kinder, K., Achworth, M., Montgomery, A., Moore, H., and Wilkin, A. (1999). Real Curriculum: at the end of Key Stage 2: report one from the Northern Ireland Curriculum Cohort Study. Slough, NFER.

Jeffrey, B., and Woods, P. (1996). Feeling de-professionalised: the social construction of emotions during an Ofsted inspection. Cambridge Journal of Education, 26(3), 325-343. http://dx.doi.org/10.1080/0305764960260303

Kinder, K., Wakefield, A., and Wilkin, A. (1996). Talking Back: pupil views on disaffection. Slough, NFER.

Lord, P., and Jones, M. (2006). Pupils' Experiences and Perspectives of the National Curriculum and Assessment: final report of the research review. Slough, NFER.

MacBeath, J., Demetriou, H., Ruddock, J. and Myers, K. (2003), Consulting pupils: a toolkit for teachers, Cambridge, Pearson Publishing.

MacGilchrist, B., and Buttress, M. (2005). Transforming Teaching and Learning. London: Paul Chapman.

McCallum and Demie, F. (2001). Social Class, ethnicity and educational performance. Educational Research, 43(2), 147-159. http://dx.doi.org/10.1080/00131880110051146

Noyes, A. (2005). Pupil voice: purpose, power and possibilities for democratic schooling. British Educational Research Journal, 31(4), 533-540. http://dx.doi.org/10.1080/01411920500153614 


\section{Macrothink}

International Journal of Education ISSN 1948-5476 2012, Vol. 4, No. 3

Pell, T., and Jarvis, T. (2001). Developing attitudes to science for use with children aged from five to eleven years. International Journal of Science Education, 23(8), 847-862. http://dx.doi.org/10.1080/09500690010016111

Pointon, P., and Kershner, R. (2000). Making decisions about organising the primary classroom environment as a context for learning: the views of three experienced teachers and their pupils - the child's environment. Teaching and Teacher Education, 16(1), 117-127. http://dx.doi.org/10.1016/S0742-051X(99)00043-8

Pollard, A. (1996). Playing the system? Pupil perspectives on curriculum, pedagogy and assessment in primary schools. In P. Croll (Ed), Teachers, Pupils and Primary Schooling: continuity and change. London: Cassell.

Pollard, A., and Filer, A. (1996). The Social World of Children's Learning: case studies of pupils from four to seven,. London: Cassell.

Pollard, A., Triggs, P., With Broadfoot, P., McNess, E., and Osborn, M. (2000). What Pupils Say: changing policy and practice in primary education. London and New York: Continuum.

Reay, D., and Wiliam, D. (1999). I'll be a nothing: structure, agency and construction of identity through assessment. British Educational Research Journal, 25(3), 343-354. http://dx.doi.org/10.1080/0141192990250305

Reid, N., and Skryabina, E.A. (2002). Attitudes towards physics. Research in Science and Technology Education, 20(1), 67-81. http://dx.doi.org/10.1080/02635140220130939

Robson, C., and Fielding, M. (2010). Children and their Primary Schools: pupils' voices, in Alexander, R. (2010) (Ed), The Cambridge Primary Review Research Surveys. London: Routledge pp.17-48.

Ruddock, J., and Flutter, J. (2004). How to Improve your School. London: Continuum.

Silcock, P., and Wyness, M.G. (2000). Diligent and dedicated: primary school pupils talk about the reformed curricula. Curriculum, 21(1), 14-25.

Woods, P., and Jeffrey, B. (2002), 'The reconstruction of primary teachers' identities', British Journal of Sociology of Education, 23(1), 89-106. http://dx.doi.org/10.1080/01425690120102872

\section{Copyright Disclaimer}

Copyright reserved by the author(s).

This article is an open-access article distributed under the terms and conditions of the Creative Commons Attribution license (http://creativecommons.org/licenses/by/3.0/). 